\title{
A QUALITATIVE ANALYSIS OF BIOMASS FLOW SENSING BEHAVIOR USING CAPACITIVE TECHNIQUE
}

\author{
Rumana TASnim ${ }^{1}$, Sheroz Khan ${ }^{2}$, Musse MOHAMUd ${ }^{2}$ ANd Atika ARShAD ${ }^{2}$ \\ ${ }^{I}$ Department of Mechatronics Engineering, World University of Bangladesh, Bangladesh \\ ${ }^{2}$ Department of Electrical and Computer Engineering, International Islamic University \\ Malaysia, Malaysia \\ Irumanatasnim415@gmail.com,sheroz@iium.edu.my,mussemoh@yahoo.com,and \\ atikaarshad@hotmail.com \\ (Received: 17 May. 2013; Accepted: 23 Apr. 2015; Published on-line: 30 Apr. 2016)
}

\begin{abstract}
Flowsensing technology from today's application perspective has gained significant research interest over the past few years. Among the existing sensing techniques, electrostatic and capacitive sensing techniques have proven promising although cable capacitance and stray capacitance cause inaccuracy while measuring very small capacitances. The existing measurement circuit model is complicated and has flawed electrode arrangement. By sensing very small capacitive variation, the developed capacitive technique has proven capable of reducing the stray and residual capacitance effect by using an interface sensing circuit based on circular and semicircular shaped electrode and modified capacitive bridge. The proposed interface circuit is simulated via PSPICE for realizing the small capacitive variation with permittivity variation. Hardware implementation is carried out using a flow sensing set up that senses two kinds of biomass flow variation as a change of dielectric permittivity under room conditions. The output voltage has been reproduced as a representative of the flow. Moreover, a comprehensive investigation into experimental data shows an agreeable level of consistency with the simulation results.
\end{abstract}

ABSTRAK: Dari perspektif pemakaian semasateknologi penderiaan aliran menimbulkan faedah penyelidikan yang ketara sejak beberapa tahun kebelakangan ini.Antara teknik penderiaan semasa teknik penderiaan elektrostatik dan kapasitif terbukti berkesan walaupun kemuatan kabel dan kemuatan sesat menyebabkan ketidaktepatan serta mengukur kapasitans yang sangat kecil.Model litar pengukuran sedia ada adalah rumit dan mempunyai susunan elektrod yang cacat.Dengan mengesan perubahan kapasitif sangat kecil, teknik kapasitif yang dibina ini telah terbukti mampu mengurangkan kesan kemuatan sesat dan sisa melalui penggunaan litar antara muka penderiaan berdasarkan elektrod yang berbentuk bulat dan separuh bulat dan kapasitif sambunganyang diubahsuai.Litar antara muka yang dicadangkan adalah simulasi menggunakan PSPICEyang mampu mendapatkankan perubahan kapasitif kecil dengan perubahan ketelusan.Pembinaan perkakasan menggunakan kaedah penderiaan aliran yang mengesan perubahan aliran dua jenis biomass sebagai perubahan ketelusan dielektrik dalam keadaan bilik.Voltan keluaran telah dihasilkan semula untuk menunjukkan aliran. Siasatan menyeluruh pada data eksperimen menunjukkan tahap yang konsisten dengan hasil simulasi.

KEYWORDS: Electrodes; Sensing; Capacitance; Electrostatic; Piping; Measurement 


\section{INTRODUCTION}

Suitable instrumentations for on-line monitoring and measurement in gas-solid twophase flow has proven to be an exigent task for scientists and researchers at universities and institutes. The term 'gas-solid flow' signifies dilute or dense phase flow with a very little concentration of solids. For conducting such flow measurement generally velocity and volumetric concentration of the flow particles are needed to be measuredSolids are foundas powder and grain being carried in air that has various applications in industries namelychemical, pharmaceutical, food processing. Also, while flowing agricultural particles (e.g., grains, wheat, corn) [1] as well as transporting pulverized coal in fuel lines of thermal power stations. Electrostatic and capacitive methods [2-3] are the most reliable electrical sensing techniqus for solid flow measurement techniques. High sensitivity and cost effectiveness of capacitance sensing make the measurementof concentration and velocity of solid particles the most effective sensing solutions. Some research works have been done onnovel electrode design and such designs were tested as versatile hardware platform for suiting in industrial sector [4]. In order to convert capacitance-to-digital (CDC), few capacitance measurement schemes [5-6] were implemented in Integrated Circuit (IC). A promising capacitive sensing technique [7] based on stainless steel source grid sensing electrodes to increase high and homogeneous capacitance sensitivity over the pipe cross section was developed by some researchers for measuring pulverized fuel concentration in a laboratory scale pneumatic conveying system along with the calibration facility. Holler et al., [8] projected a sensing principle based on a multi-electrode structure (eleven ring shaped) in order to increases the sensitivity to dielectric permittivity variations. However, proper characterization of flow particles was not done in this technique which results in providing inaccurate information about flow. Recently some authors [9], presented flow velocity measuring electrostatic sensing technique using circular and arc-shaped sensor arrays. Online continuous measurement of "mean" and "local" characteristics of blended biomass flow is done. From the reviewed papers it is apparent that different electrode structure design and optimization along with pipeline, complicated capacitance measurement circuits have been developed previously. Although not much research has been undertaken on the perception of biomass sensing behaviour in term of signal detected from the measurement circuit which influences the measurement procedure of concentration and velocity of biomass particles. Furthermore, biomass transportation by air is unpredictable owing to the particles' complicated physical characteristics. It results in insufficient industrial biomass process; so the prospective of biomass as renewable energy source is still unrealized. This paper aims to analyze on biomass flow sensing behaviour by making use of a cost effective and simple measurement interface circuit (that reduces stray and residual capacitance) along with two designed semi-circular and circular shaped capacitive electrodes.

\section{SYSTEM ARCHITECTURE}

To conduct real-time flow measurement, a capacitance sensing techniqueis developed.The capacitive sensor is constructed with a pair of conductive sensing electrodes with the placement of dielectric material in between them. The parameter which determines capacitance change in the developed capacitive sensor are the flow of biomass materials. The excitation voltage combined with measurement circuits can transform capacitance variations into a voltage. The block diagram of this research work is illustrated in Fig. 1. The system structure which consists of a sensing segment and a processing part is shown in Fig. 2. The experimental set up and two types of electrodesis are shown in Fig. 3(a) and (b) respectively. 


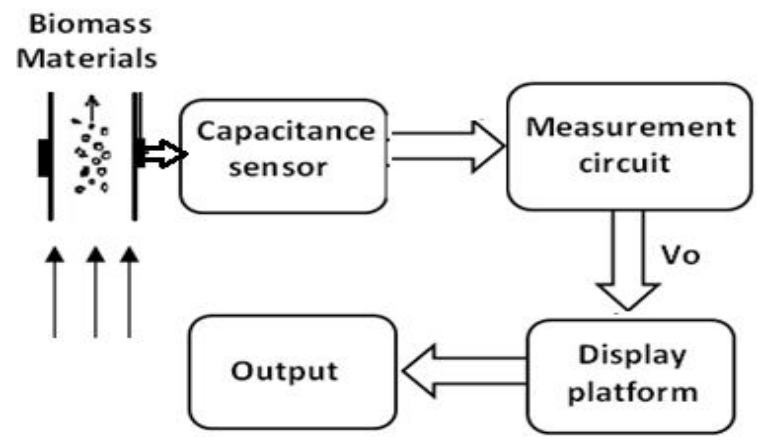

Fig. 1: Block diagram of a capacitive sensing technique.

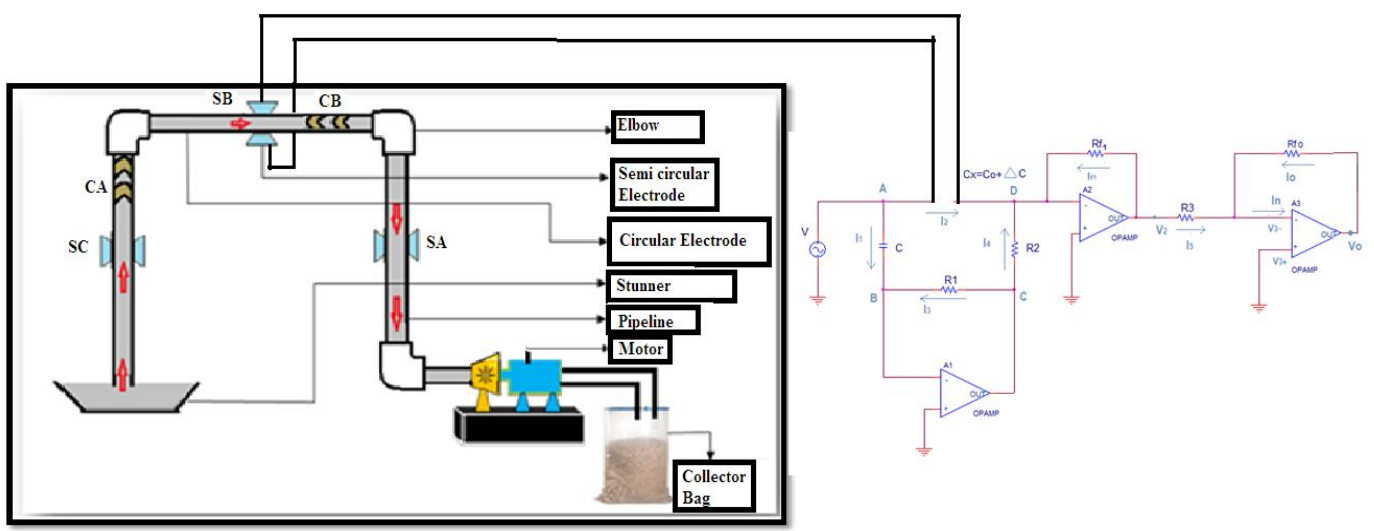

Fig. 2: Integrated sensing and processing unit of system.

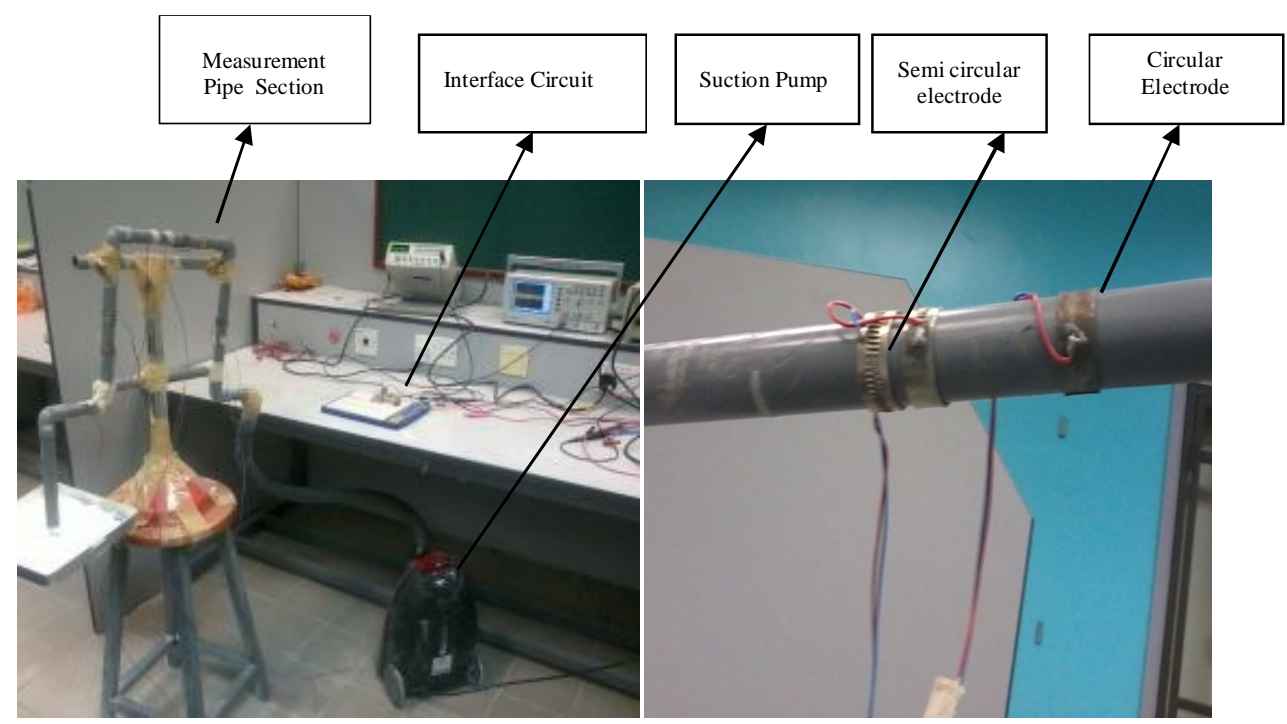

(a)

(b)

Fig. 3: (a)Experimnetal set-up, and (b) Circular and semicircular electrode.

The biomass is pneumatically sucked by an industrial suction pump located at the far end through the pipe, on which five pairs of electrodes are mounted. A biomass collector 
bag is placed at the other end.The test pipe section is of $1000 \mathrm{~mm}$ with an upward flow direction and made of polyvinyl chlorides. The inside and outside diameter of the pipe is $25 \mathrm{~mm}$ and $27 \mathrm{~mm}$ respectively. The biomass test materials are wheat and fodder (agricultural grain). Ground grain (wheat) is replicated as fine biomass base. An inexpensive solely noncontact circular (e.g., CA, CB; made of mild steel) and semi-circular (e.g., SA. SB, SC; made of galvanized steel) capacitive electrodes make one arm of the bridge circuit. The electrode's width is chosen as $\mathrm{W}=12 \mathrm{~mm}$, electrode separation $\mathrm{d}=3 \mathrm{~mm}$, the ratio of capacitive sensor electrode width (W) to electrode separation (d) is $4: 1$, the number of electrodes, $\mathrm{K}=10$ and radius of the pipe $\mathrm{r}=12.5 \mathrm{~mm}$. The measurement interface circuit (in processing part in Fig.2) is an inexpensive operational amplifier based capacitance bridge circuit [10]. This measurement circuit detects very small capacitance variation because of the change in biomass flow medium. The flow pipe is inserted as a lone arm of the bridge, while the upper arms are made up of fixed and variable capacitances. An identical potential is sustained at the output nodal points of bridge circuit which reduces the effect of the stray capacitance between the output leads of bridge network. The lower bridge arms are made up of resistors to keep point B at a virtual ground to improve the flow stability by variable capacitance arm, Cx. The middle OP-AMP offers adjustable sensitivity to overall output and the third OP-AMP stops the load from having any effect on the measurement. The interface circuit is analysed through the mathematical derivation of proportional relationship between output voltage and capacitance changes [derived in Eqn 5]. The bridge circuit is balanced (no flow) only when CR1= CR2.

From Fig.2, the current through $I_{1}$ is given by $A B=j V C \omega$; current through $I_{2}$ is $A D=j V C x \omega$; current through $I_{3}$ is $B C=\frac{V_{1}}{R_{1}} ; I_{4}$ is $C D=\frac{V_{1}}{R_{2}} ; I_{f 1}=\frac{V_{2}}{R_{f 1}}$

Using Kirchhoff's law, $\quad I_{1}+I_{3}=0$

$$
j V C \omega+\frac{V_{1}}{R_{1}}=0
$$

Hence $V_{1}=-j V C \omega R_{1}$

$$
\text { Again } I_{2}+I_{4}+I_{f}=0
$$

Substituting the values we will get,

$$
\begin{aligned}
& \Rightarrow j v c_{\mathrm{x}} \omega+\mathrm{V}_{1} / \mathrm{R}_{2}+\mathrm{V}_{2} / \mathrm{R}_{\mathrm{f} 1}=0 \\
& \Rightarrow \mathrm{V}_{2} / \mathrm{R}_{\mathrm{f} 1}=-j v c_{\mathrm{x}} \omega-\mathrm{V}_{1} / \mathrm{R}_{2} \\
& \Rightarrow \mathrm{V}_{2} / \mathrm{R}_{\mathrm{f} 1}=-j v\left(c_{0}+\Delta \mathrm{C}\right) \omega-\mathrm{V}_{1} / \mathrm{R}_{2} \\
& \Rightarrow V_{2} / R_{\mathrm{f} 1}=\frac{-j v c_{0} \omega R_{2}-j v \Delta C \omega-V_{1}}{R_{2}} \\
& \Rightarrow V_{2} / R_{\mathrm{f} 1}=\frac{-j v \omega\left[c_{0} R_{2}+\Delta C\right]-V_{1}}{R_{2}}
\end{aligned}
$$




$$
\begin{aligned}
& \Rightarrow V_{2} / R_{\mathrm{f} 1}=\frac{-j v \omega\left[C R_{1}+\Delta C\right]-V_{1}}{R_{2}} \\
& \Rightarrow V_{2} / R_{f 1}=\frac{-j v \omega C R_{1}-j v \omega \Delta C+j v \omega C R_{1}}{R_{2}} \\
& \Rightarrow V_{2} / R_{f 1}=\frac{-j v \omega \Delta C}{R_{2}} \Rightarrow \\
& \Rightarrow V_{2}=\frac{-j \omega R_{f 1}}{R_{2}} v \Delta C \\
& \quad V_{2}=-j \omega R_{f} V\left(C_{x}-C_{0}\right)
\end{aligned}
$$

Employing a single node voltage equation at the inverting terminal of the buffer which acts as an inverting amplifier, we get;

$$
\mathrm{I}_{5}+\mathrm{I}_{\mathrm{o}}=\mathrm{I}_{\mathrm{n}}
$$

As the voltage at $\mathrm{V}_{3}^{+}=0, \mathrm{~V}_{3}^{-}=0$

As differential input voltage is zero, $\mathrm{V}_{3}^{+}=\mathrm{V}_{3}^{-}=0$

So, $\mathrm{I}_{5}=\frac{\mathrm{V}_{2}}{\mathrm{R}_{3}}$ and $\mathrm{I}_{\mathrm{o}}=\frac{\mathrm{V}_{\mathrm{o}}}{\mathrm{R}_{\mathrm{fo}}}$

Ideally the equivalent input resistance is infinite resulting $\mathrm{I}_{\mathrm{p}}=\mathrm{I}_{\mathrm{n}}=0$

From Equation (4) we can write, $I_{5}+I_{0}=0$

$$
\begin{gathered}
\Rightarrow \frac{V_{2}}{R_{3}}+\frac{V_{o}}{R_{f o}}=0 \\
\Rightarrow \frac{V_{2}}{R_{3}}=-\frac{V_{o}}{R_{f o}} \\
\Rightarrow V_{o}=-\frac{R_{f o}}{R_{3}} \times V_{2} \\
\text { Since } V_{2}=\frac{-j \omega R_{f 1}}{R_{2}} v \Delta C \\
\text { So, } V_{o}=\frac{j \omega R_{f o} R_{f 1}}{R_{3} R_{2}} v \Delta C
\end{gathered}
$$

The Output voltage of the circuit, $V_{o}=\frac{j \omega v R_{f o} R_{f 1}}{R_{3} R_{2}} v\left(C_{x}-C_{0}\right)$

\section{RESULTS AND DISCUSSION}

The processing circuit was simulated initially using PSPICE. The simulation is supported by experimental validation, clearly showing how this work has been successful in sensing two type of biomass materials. The simulation and experimental validation of the results on the instrumentation part of this work are detailed below. 
In balanced condition, the values chosen are, $\mathrm{C}=10 \mathrm{pF}, \mathrm{Co}=10 \mathrm{pF}, \mathrm{R} 1=1 \mathrm{k} \Omega$ (standard resistance), $\mathrm{R} 2=1 \mathrm{k} \Omega, \mathrm{R} 3=10 \Omega$. When the circuit will be balanced, then $\mathrm{CR} 1=\mathrm{CR} 2$. The sensitivity factor; Rf1 $=100 \mathrm{~K} \Omega, \mathrm{Rf} 2=100 \mathrm{k} \Omega$. Figure $4(\mathrm{a})$ and $4(\mathrm{~b})$ shows the simulation Circuit for balanced condition and the simulation output.

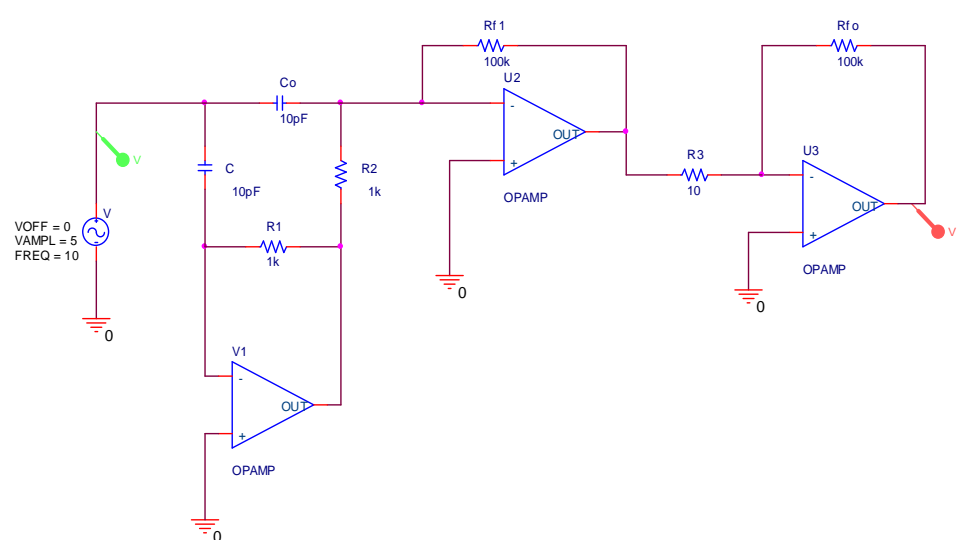

Fig. 4(a): Simulation Circuit for balanced condition.

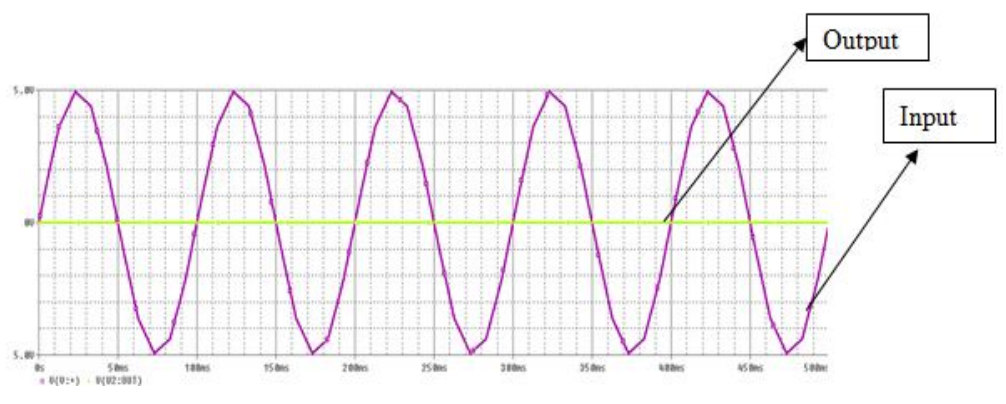

Fig. 4(b): Simulation results for balanced condition.

When the circuit goes unbalanced; $\mathrm{Cx}=20 \mathrm{pF}, \mathrm{C}=10 \mathrm{pF}, \mathrm{R} 1=1 \mathrm{k}$, (standard resistance), $R 2=4.7 k, R 3=10 . C R 1$ is not equal to CR2, Sensitivity factor; Rf1=100 k, Rf2 $=100 \mathrm{k}$ (which can be changed for bridge sensitivity). Figure 5 shows simulation result for unbalanced condition. The simulation approach was later supported by experimental validation for achieving desired research objectives. The experimental steps along with results are discussed below.

Air flow is produced by turning on a suction pump, withan air velocity which is kept fixed. An excitation voltage (10V AC) with a stabilized frequency of $10 \mathrm{~Hz}$ is applied to excite the bridge network. A LCR meter measures the capacitance changes. The experimental setup is first tested when the bridge is balanced under no-flow conditions only to be unbalanced with biomass flow. The circuit is first tested by flowing light weight fodder biomass which has $500 \mu \mathrm{m}$ diameter and moves faster than wheat $(100 \mu \mathrm{m})$. Figure 6(a)6(b) shows fodder flow sensing behaviour (voltage outputs and capacitance graphs) at $1000 \mathrm{~g} / \mathrm{min}$ over 60 seconds involving 10 seconds step. Electrodes' location made a significant impact on the sensing phenomenon. Semi-circular electrode SC fitted near to the container has obtained the highest output voltage (8.5-9.3V) along with maximum capacitance (90.5-91.6pF). Horizontally positioned SB electrodes exhibited lowest and 
relatively less fluctuated capacitance values $(65.6-68 \mathrm{pF})$ which depicted an almost stable graph. In case of galvanized iron semi-circular electrode; SA mounted on the vertical pipe section near to the suction pump showed fluctuated voltage whereas the capacitance sensed by this electrode depicted a stable graph with no noticeable fluctuation.

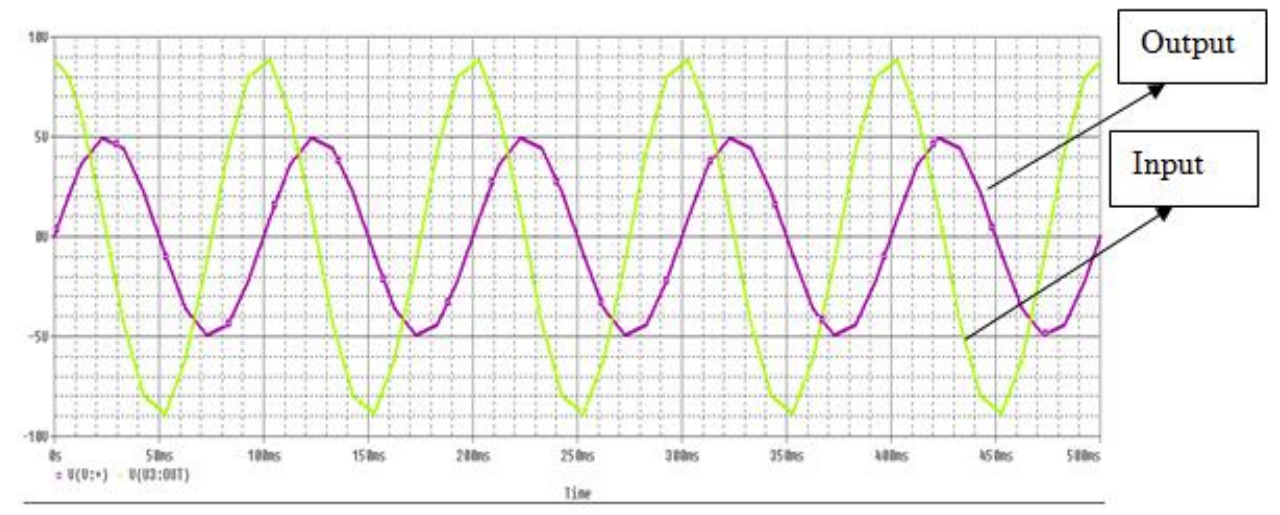

Fig. 5: PSPice simulation result for unbalanced condition (with $\mathrm{Cx}=30 \mathrm{pF}$ ).

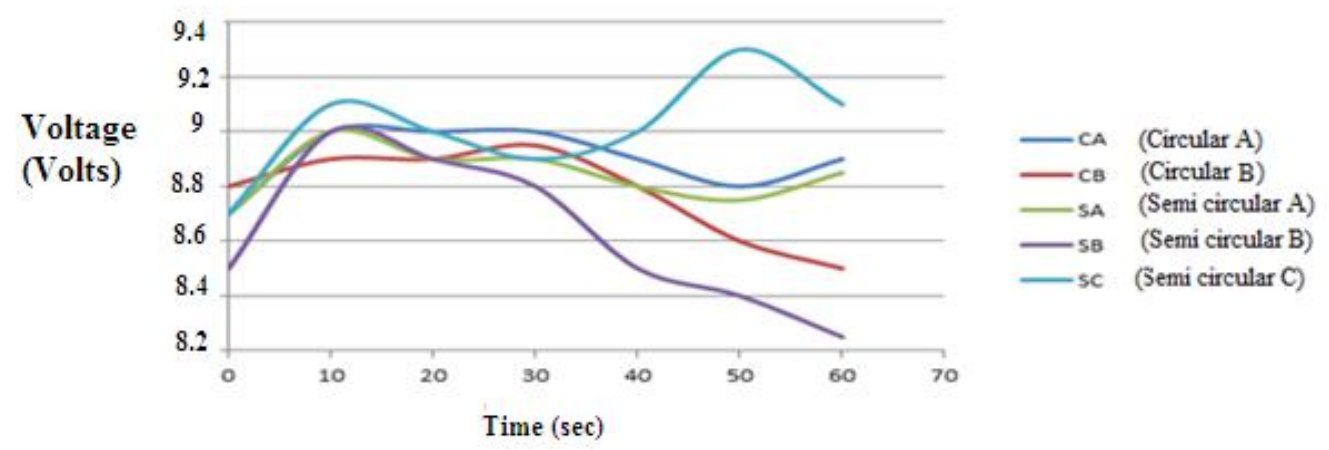

(a)

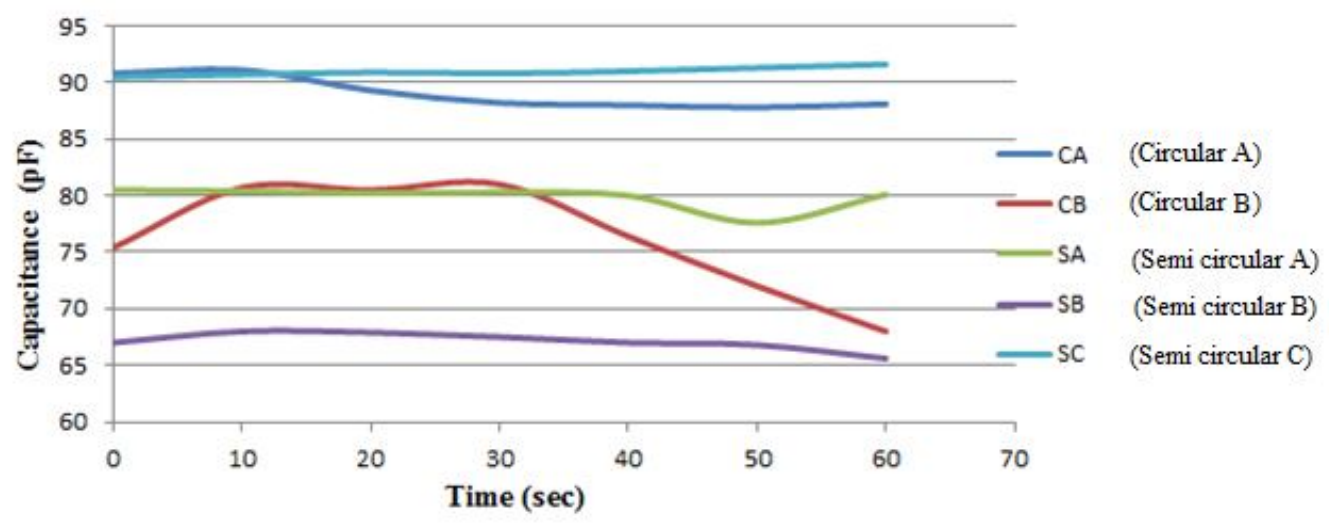

(b)

Fig. 6: (a) Voltage output, (b) Capacitance as a function of fodderflow (1000g/min).

The circular electrodes showed ups and downs in a minimal variation. Both horizontally positioned SB and CB showed matching behaviour in measured voltages where after a certain period graphs declined. Also the galvanized iron electrodes are proved to be 
more sensitive due to the better conductivity than the other ones. Fine particle wheat $(100 \mu \mathrm{m})$ is replicated as a ground grain fine particle. Figure 7(a)-(b) illustrated voltage and capacitance variation as a function of wheat flow $(600 \mathrm{~g} / \mathrm{min})$.

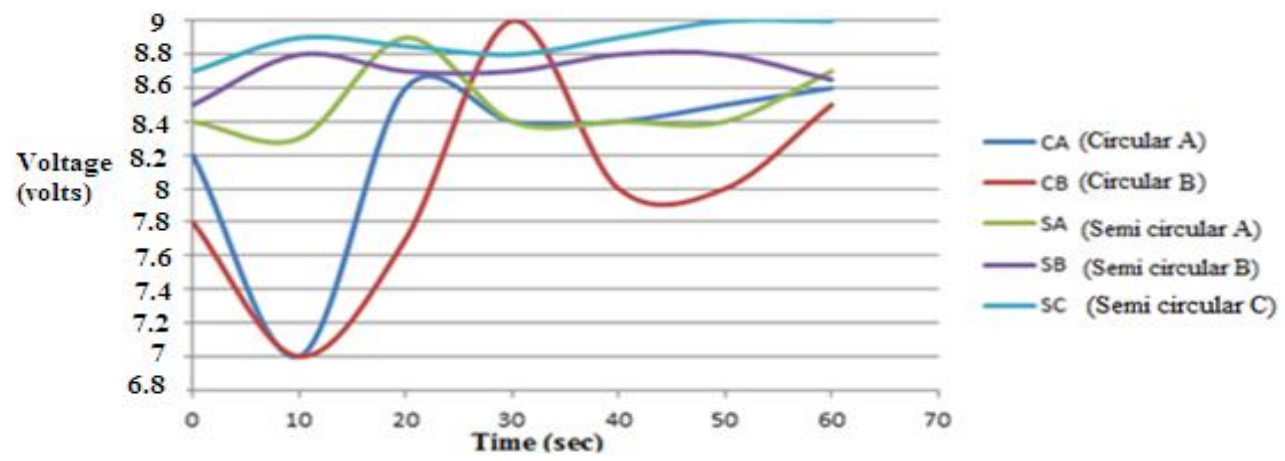

Fig. 7(a): Voltage output as a function of wheat flow.

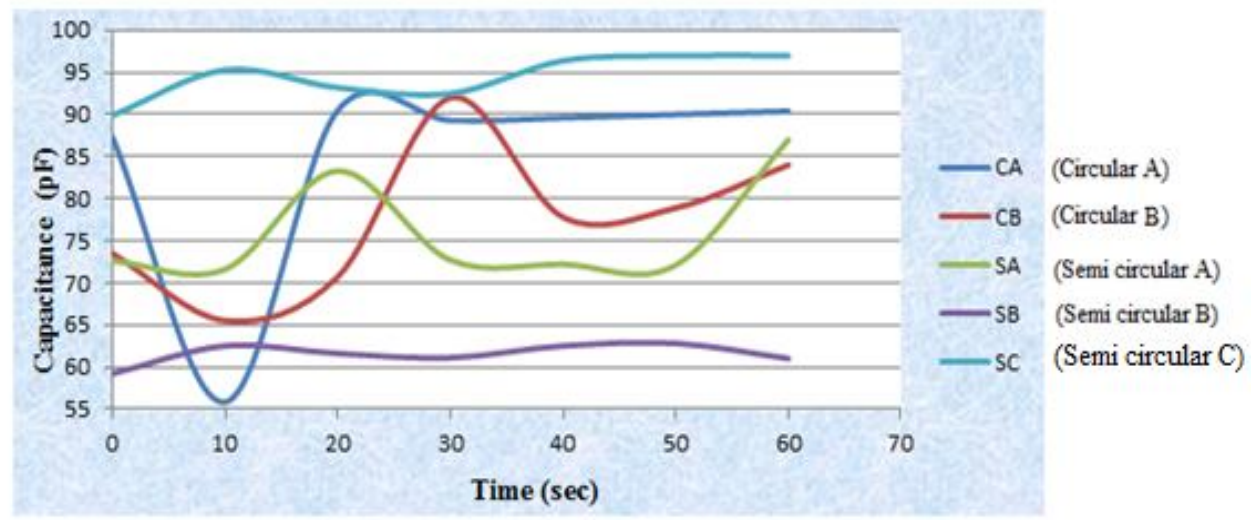

Fig. 7(b):Capacitance as a function of wheat flow range.

The variation of wheat materials flow range has been sensed well by circular electrodes while semicircular electrodes have shown steady response. Similar kind of behaviours is observed also in case of wheat material. From the analysis of experimental and simulated voltages, the semi-circular electrodes show better sensitivity. To analyze the conformity between simulated and experimental results, simulation has been carried out using PSPice for the capacitances obtained from the experimental results, first under balanced conditions and then under unbalanced condition, the product CR1 being unequal to the product CR2, led to an output voltage. A set of simulation results are obtained for the experimentally obtained results for fodder flow sensed by SA ( Table 1).

Table 1: Experimental and simulated output voltages ascended (sensed by SA)

\begin{tabular}{ccc}
\hline Capacitance(pF) & Experimental voltage & Simulation voltage \\
\hline 77.6 & 8.75 & 8.4 \\
80 & 8.8 & 8.5 \\
80.1 & 8.85 & 8.54 \\
80.2 & 8.9 & 8.5 \\
80.3 & 8.9 & 8.6 \\
80.4 & 9 & 8.6 \\
\hline
\end{tabular}




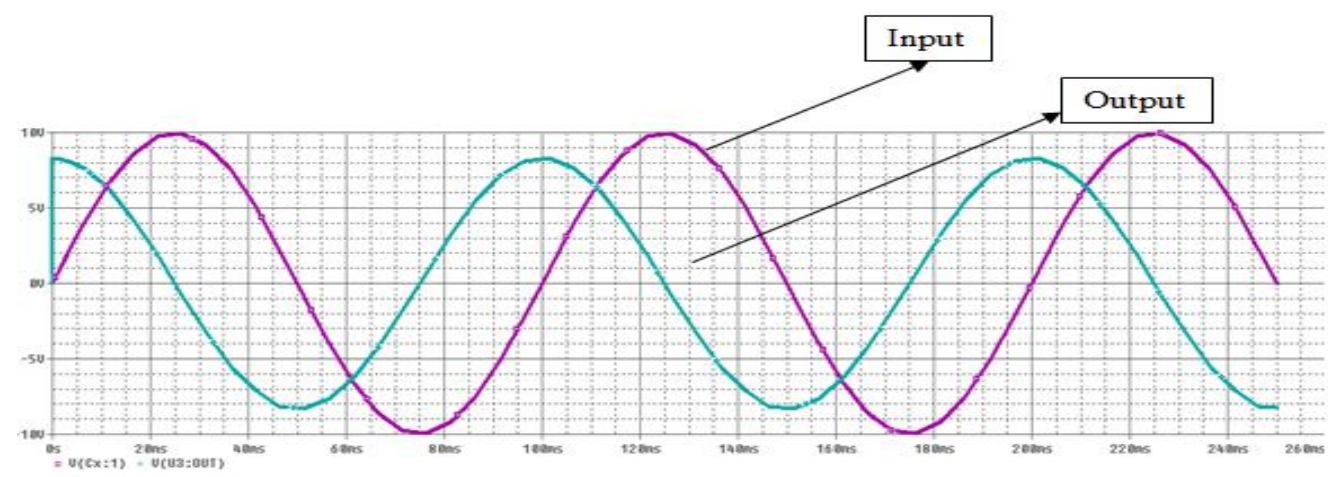

Fig. 8(a): Simulation Output for $77.6 \mathrm{pF}$ capacitance.

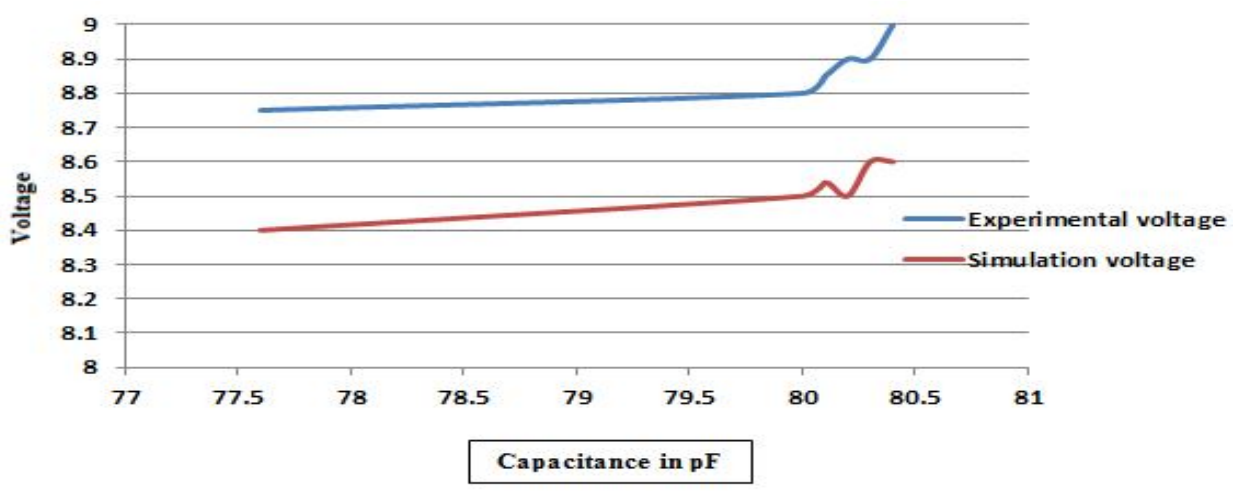

Fig. 8 (b): Experimental and simulation voltage for fodder flow across SA.

Figure 8(a) depicts the simulation results distinctively for a specific capacitance of 77.6 $\mathrm{pF}$. The tabulated experimentally obtained capacitance values and simulated results are plotted in Figure 8(b) to validate conformity between the results. Figure 8(b) shows that, simulation and experimental results are consistent in terms of output voltage variation, with minimal discrepancy towards higher capacitance changes. With larger capacitance changes the output voltages starts showing nonlinear response. Likewise another set of simulation results are obtained for experimental values which is depicted in Table 2 and plotted in Fig. 9. Figure 9 illustrates the simulation and experimental results which show identical pattern of variation having similar slope, but the simulation show better sensitivity than the experimental.

Table 2: Experimental and simulated output voltages ascended (sensed by CA)

\begin{tabular}{ccc}
\hline capacitance $(\mathbf{p F})$ & Voltage (Experimental) & Voltage (Simulation) \\
\hline 87.8 & 8.8 & 9.4 \\
88 & 8.9 & 9.5 \\
88.1 & 8.9 & 9.5 \\
88.2 & 9 & 9.5 \\
89.3 & 9 & 9.6 \\
91.1 & 9 & 9.9 \\
\hline
\end{tabular}




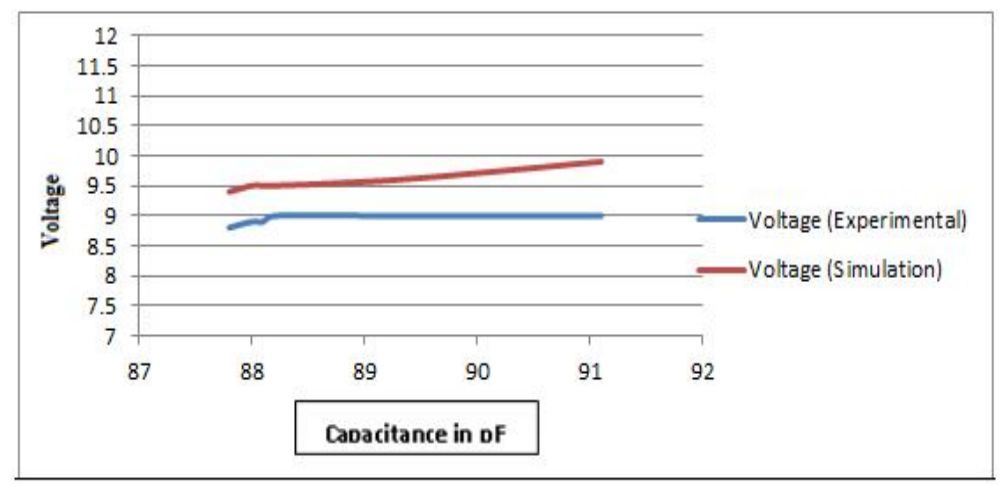

Fig. 9: Experimental and simulation voltage for fodder biomass flow sensed by CA.

Figure 9 also suggests, with the increase of capacitance values, the simulation and output voltage starts to show nonlinear response. From the above results it is apparent that, semicircular electrodes showed better sensitivity in output voltages. Once again similar set of simulation results is achieved for the experimentally obtained capacitances using other electrodes and also in case of fine particle wheat. The results obtained show almost similar patterns with a small variation in the output voltage range. In case of fodder, simulation and experimental consistency has been proven to be relatively more linear for semicircular electrode rather than circular ones.

The capacitive measurement of biomass (fodder and wheat) concentration obtains solid phase concentration by measuring the capacitance of capacitive sensor based on the established relationship between solid phase concentration and measurement capacitance $\left(\mathrm{C}_{\mathrm{X}}\right)$.

$$
\rho=\rho_{s}\left(C_{x}-k^{\prime} \epsilon_{g}\right) / k^{\prime}\left(\epsilon_{s}-\epsilon_{g}\right)
$$

Where, $\rho=$ biomass (solid phase) concentration,

$\rho_{s}=$ biomass (solid phase) density

$\epsilon_{s}=$ biomass (solid phase) permittivity

$\epsilon_{g}=$ air (gas phase) permittivityb

$k^{\prime}$ is addressed by structure and dimension of capacitance sensor plates

$$
\left(\mathrm{C}_{\mathrm{X}}\right)=\text { measurement capacitance }\left(\mathrm{C}_{\mathrm{X}}\right)
$$

From equation (5), $V_{\mathrm{o}} \mathrm{R}_{3} \mathrm{R}_{2}=-\mathrm{j} \omega v \mathrm{R}_{\mathrm{fo}} \mathrm{R}_{\mathrm{f} 1}\left(\mathrm{C}_{\mathrm{x}}-\mathrm{C}_{0}\right)$

$$
\Rightarrow j \omega v R_{f o} R_{f 1} C_{x}=j \omega v R_{f o} R_{f 1} C_{0}-V_{o} R_{3} R_{2}
$$

$$
\Rightarrow C_{x}=\frac{j \omega v R_{f o} R_{f 1} C_{0}-V_{o} R_{3} R_{2}}{j \omega v R_{f o} R_{f 1}}
$$

$\Rightarrow C_{x}=C_{0}-\frac{V_{o} R_{3} R_{2}}{j \omega v R_{f o} R_{f 1}}$

And from equation (6), 


$$
\begin{aligned}
& \rho=\rho_{\mathrm{s}}\left(\mathrm{C}_{\mathrm{x}}-\mathrm{k}^{\prime} \in_{\mathrm{g}}\right) / \mathrm{k}^{\prime}\left(\epsilon_{\mathrm{s}}-\epsilon_{\mathrm{g}}\right) \\
& \Rightarrow \rho=\rho_{\mathrm{s}}\left[\left\{\mathrm{C}_{0}-\frac{\mathrm{V}_{\mathrm{o}} \mathrm{R}_{3} \mathrm{R}_{2}}{\mathrm{j} \omega \mathrm{v} \mathrm{R}_{\mathrm{fo}} \mathrm{R}_{\mathrm{f} 1}}\right\}-\mathrm{k}^{\prime} \epsilon_{\mathrm{g}}\right] / \mathrm{k}^{\prime}\left(\epsilon_{s}-\epsilon_{\mathrm{g}}\right)
\end{aligned}
$$

So, biomass concentration is derived with respect to measured capacitance and voltage output in equation (7). This has established a correspondence relationship between biomass concentrations with biomass and air phase density, dielectric permittivity of test biomass materials as well the physical characteristics and structure of the capacitive electrode. The experimental results have shown likewise behaviour.

\section{CONCLUSION}

The experimental and simulation results obtained for a particular flow regime in the case of distinctive biomass materials has been observed, where the output voltage has become the representative of flow, as a measure of small capacitance change (in $\mathrm{pF}$ ) which proves the mathematical derivation. For real time biomass flow sensing as well as measurement, the outcome of this research work has proven to be successful by setting up a prototype experimental setup.The general observations on the overall results have shown significant effects on electrodes' shapes, location of electrodes on the piping system, biomass material type and its' individual characteristics. The proposed sensing unit will be connected with data processing unit from where the plant operators will be able to pass on useful data for improving flow control system performance. The novelty of this research lies in the use of cost effective operational amplifier based capacitive sensing circuit along with two specifically designed measuring electrodes for analyzing biomass flow sensing behaviour. As a whole, this work investigates and analyzes biomass flow sensing behaviour in order to open up a branch of research for practical implementation.

\section{REFERENCES}

[1] Heping Cui \& John R. Grace (2006). "Pneumatic conveying of biomass particles: a review", China Particuology, Vol. 4, No.3-4, pp.183-188.

[2] Yan, Y. (1995). "Flow rate measurement of bulk solids in pneumatic pipelines: problems and solutions". Bulk Solids Handling, Vol. 6, No. 3, pp. 447-56.

[3] Yan, Y. (1996). "Mass flow measurement of bulk solids in pneumatic pipelines". Measurement Science and Technology, Vol. 7, No.12, pp.1687-706.

[4] Hrach, D., \& Fuchs, A. (2008). "Investigation of field electrode geometries in capacitive flow measurement". IEEE Sensors 2008, pp. 17-20.

[5] Brasseur, G., Brandstatter, B., \& Zangl, H. (2003). "State of the Art of Robust Capacitive Sensors". IEEE Transactions on Instrumentation and Measurement, Vol. 52, No.4, pp. 12611265.

[6] Bretterklieber, T., Zangl, H., Hrach, D., Holler, G., Hammerschmidt, D., \& Motz, M. (2008). "Versatile Programmable Integrated Interface for Robust Capacitive Sensors". Elektrotechnik and Information stechnik, Vol. 125, No.4, pp.123-128.

[7] Hu, H.L., Xu, T.M., Hui, S. E., \& Zhou, Q.L. (2006). "A novel capacitive system for the concentration measurement of pneumatically conveyed pulverized fuel at power stations". Flow measurement and Instrumentation, Vol. 17, pp.87-92.

[8] Holler, G., Fuchs, A., \& Hrach, D. (2008). "Flow velocity determination in cryogenic media by means of capacitive sensing". Sensing Technology ICST 2008, pp. 472-476.

[9] Xiangchen Qian \& Yong Yan. (2012). "Flow Measurement of Biomass and Blended Biomass Fuels in Pneumatic Conveying Pipelines Using Electrostatic Sensor-Arrays".IEEE Transactions on Instrumentation and Measurement, Vol. 61, No.5, pp. 1343- 1352. 
[10] Bera, S.C., \& Mandal, H., (2012). "A Flow Measurement Technique Using a Noncontact Capacitance-Type Orifice Transducer for a Conducting Liquid". IEEE Transactions on Instrumentation and Measurement, Vol. 61, No. 9, pp.25-53 